\title{
A Primary Bone Diffuse Large B-Cell Lymphoma with Ocular Adnexal Involvement
}

\author{
Oküler Adneks Tutulumu Olan Kemiğin Primer Diffüz Büyük B Hücreli Lenfoması
}

\author{
Rafet Eren1, Ceyda Aslan¹, Cihan Gündoğan², Osman Yokuş¹, Mehmet Hilmi Doğu¹, Elif Suyanı \\ 1istanbul Training and Research Hospital, Clinic of Hematology, Istanbul, Turkey \\ 2istanbul Training and Research Hospital, Clinic of Nuclear Medicine, Istanbul, Turkey
}

To the Editor,

Primary bone lymphomas (PBLs) $[1,2]$ and ocular adnexal (OA) lymphomas $[3,4]$ are rare types of extranodal lymphomas. Coexistence of these two rare entities without lymph node infiltration has not been reported previously.

A 55-year-old man presented with left hip pain without a history of trauma. His medical history and physical examination did not reveal any remarkable findings. The $\mathrm{X}$-ray radiographs of the pelvis and left hip showed multiple lytic lesions. Body 18fluorodeoxyglucose positron emission tomography/computed tomography (18F-FDG PET/CT) demonstrated multiple osteolytic bone lesions in the left zygomatic bone, vertebral column, bilateral iliac bones, left caput femoris, and trochanter major of the femur with increased 18F-FDG uptake (SUVmax: 31) (Figure 1a). Tru-Cut biopsy of the caput femoris showed atypical lymphoid cells that were pancreatin (-), s-100 (-), CD138 (+), CD30 (-), CD20 (+), CD3 (-), CD5 (-), CD10 (-), bcl$6(+)$, and MUM-1 $(+)$, consistent with diffuse large B-cell lymphoma. Laboratory data were as follows: erythrocyte sedimentation rate, $37 \mathrm{~mm} / \mathrm{h}$; lactate dehydrogenase level, 405

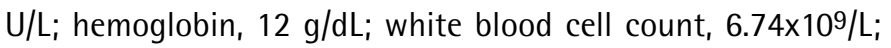
platelet count, $250 \times 109 / \mathrm{L}$; normal liver and renal function tests. Bone marrow aspirate and core biopsy were normal. A rituximab, cyclophosphamide, doxorubicine, vincristine, and prednisolone (R-CHOP) regimen was planned. However, prior to the first chemotherapy day, the patient was admitted with swelling of the eyelids, exophthalmos, proptosis, and vision loss in his left eye that developed progressively over 3 days. Magnetic resonance imaging (MRI), which was performed two months after the initial $18 \mathrm{~F}-\mathrm{FDG} \mathrm{PET} / \mathrm{CT}$, showed an orbital mass with diameters of $36 \times 21 \times 38 \mathrm{~mm}$ eroding the superior wall of the orbita and adjacent soft tissue (Figure 1b). After the detection of orbital involvement, investigations for central nervous system (CNS) involvement were negative. Chemotherapy treatment was commenced immediately without doing a biopsy because of the patient's vision loss. After 4 cycles of R-CHOP chemotherapy, the patient's left hip pain, left eye swelling, exophthalmos, and proptosis resolved completely, but his vision did not improve. Control 18F-FDG PET/CT showed marked regression of bone lesions with decreased 18F-FDG uptake (SUVmax: 4.6). Orbital MRI also showed that the mass had regressed to $14 \times 12 \mathrm{~mm}$ in size. After obtaining this response, 2 cycles of R-CHOP, radiotherapy to the left orbita, and two cycles of high-dose methotrexate for CNS prophylaxis were planned.

Considering the extensive lytic bone lesions and recent emergence of the OA tumor, the primary site of the disease must have been the bones in the presented case. Thus, the diagnosis can be categorized as PBL with OA involvement. An orbital mass was detected two months after diagnosis by means of MRI, but not by $18 \mathrm{~F}-\mathrm{FDG}$ PET/CT performed at diagnosis. It would be speculative to claim that such a large mass had arisen in a two month period. Taking into account that MRI is the gold standard imaging technique in evaluation of $\mathrm{OA}$ tumors [3], the orbital mass, which was probably small at the beginning, could not have been noticed on $18 \mathrm{~F}-\mathrm{FDG}$ PET/CT. This case emphasizes that a high suspicion index of OA involvement in PBL cases with any symptoms regarding the eyes and prompt assessment of the patients with MRI might prevent undesirable consequences.

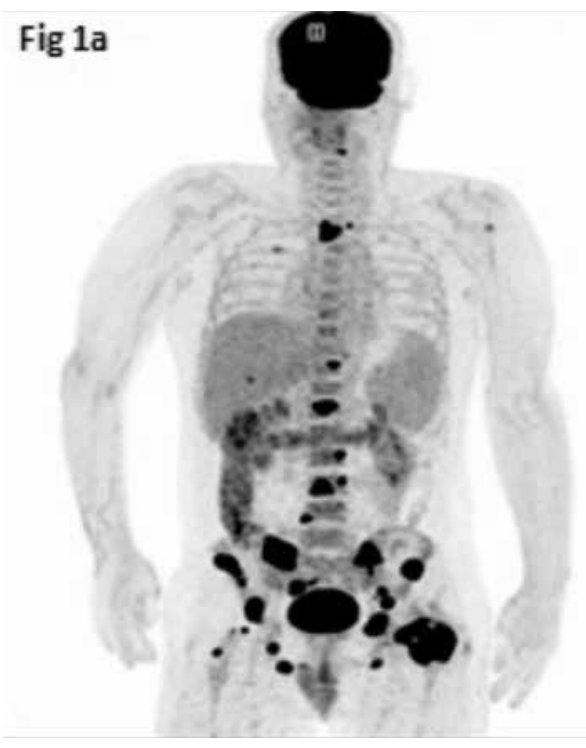

Figure 1a. 18Fluorodeoxyglucose positron emission tomography/ computed tomography image of the patient at diagnosis. 


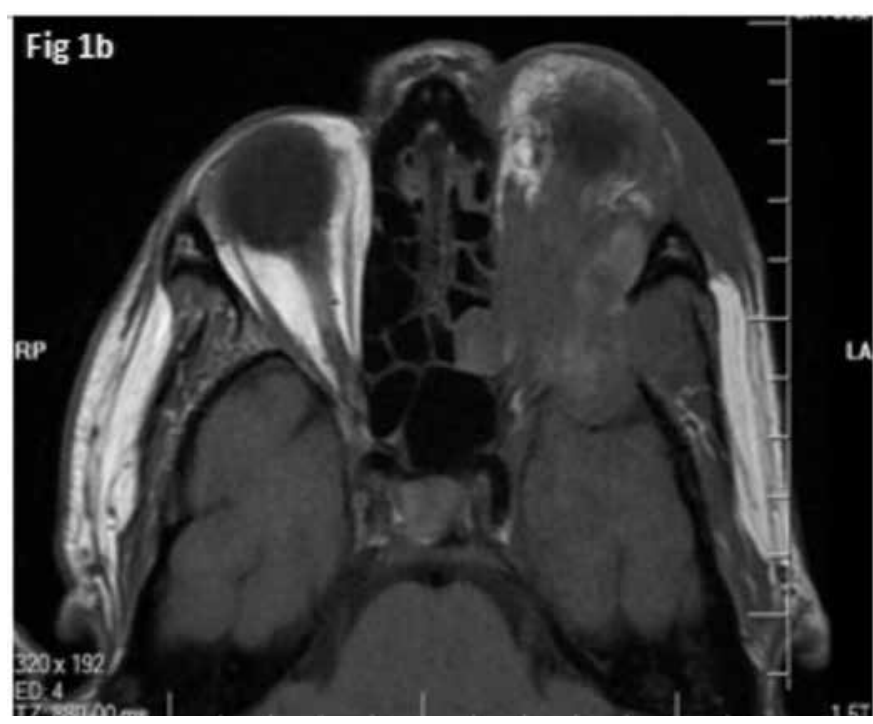

Figure $1 \mathrm{~b}$. Magnetic resonance imaging image of orbital adnexal mass.

Keywords: Primary bone lymphoma, Ocular adnexal lymphoma,

Diffuse large B-cell lymphoma

Anahtar Sözcükler: Primer kemik lenfoma, Oküler adneks lenfoma, Diffüz büyük B hücreli lenfoma

\section{Ethics}

Ethics Committee Approval: Not applicable; Informed Consent: Not applicable.

\section{Authorship Contributions}

Surgical and Medical Practices: Rafet Eren, Elif Suyanı; Concept: Rafet Eren, Ceyda Aslan, Cihan Gündoğan, Osman Yokuş, Mehmet Hilmi Doğu, Elif Suyanı; Design: Rafet Eren, Ceyda Aslan, Cihan Gündoğan, Osman Yokuş, Mehmet Hilmi Doğu, Elif Suyanı; Data Collection or Processing: Rafet Eren, Ceyda Aslan, Cihan Gündoğan, Osman Yokuş, Mehmet Hilmi Doğu, Elif Suyanı; Analysis or Interpretation: Rafet Eren, Ceyda Aslan, Cihan Gündoğan, Osman Yokuş, Mehmet Hilmi Doğu, Elif Suyanı; Literature Search: Rafet Eren, Ceyda Aslan, Cihan Gündoğan, Osman Yokuş, Mehmet Hilmi Doğu, Elif Suyanı; Writing: Rafet Eren, Ceyda Aslan, Cihan Gündoğan, Osman Yokuş, Mehmet Hilmi Doğu, Elif Suyanı.

Conflict of Interest: The authors of this paper have no conflicts of interest, including specific financial interests, relationships, and/ or affiliations relevant to the subject matter or materials included.

\section{References}

1. Messina C, Christie D, Zucca E, Gospodarowicz M, Ferreri AJ. Primary and secondary bone lymphomas. Cancer Treat Rev 2015;41:235-246.

2. Kitsoulis P, Vlychou M, Papoudou-Bai A, Karatzias G, Charchanti A, Agnantis NJ, Bai M. Primary lymphomas of bone. Anticancer Res 2006;26:325-337.

3. Ponzoni M, Govi S, Licata G, Mappa S, Giordano Resti A, Politi LS, Spagnuolo L, Di Cairano E, Doglioni C, Ferreri AJ. A reappraisal of the diagnostic and therapeutic management of uncommon histologies of primary ocular adnexal lymphoma. Oncologist 2013;18:876-884.

4. Woolf DK, Ahmed M, Plowman PN. Primary lymphoma of the ocular adnexa (orbital lymphoma) and primary intraocular lymphoma. Clin Oncol (R Coll Radiol) 2012;24:339-344

\section{Cerebral Sinovenous Thrombosis Mimicking Intracranial Mass}

\section{Intrakranial Kitleyi Taklit Eden Serebral Sinovenöz Tromboz}

Derya Özyörük

Ankara Children's Hematology and Oncology Training and Research Hospital, Ankara, Turkey

To the Editor,

Cerebral sinovenous thrombosis is rare in children [1]. Most common signs and symptoms are seizure, lethargy, and headache $[1,2,3]$. We herein report a case diagnosed as cerebral sinovenous thrombosis mimicking an intracranial mass and presenting with increased intracranial pressure symptoms in an adolescent girl.
A 16-year-old girl was admitted to our emergency service with complaints of headache, vomiting, and confusion. Her past medical history was unremarkable. Physical examination revealed facial paralysis and motor weakness on the left side. Magnetic resonance (MR) imaging disclosed a mass $(65 \times 42 \times 55 \mathrm{~mm})$ in the right temporal lobe shifting the midline structure from right to left (Figure 1). Because of herniation findings, surgery was performed immediately. Histopathologic investigation showed 